\title{
HUKUM ABORSI DALAM PERSPEKTIF INTERKONEKTIF (TINJAUAN DARI HUKUM ISLAM DAN HUKUM POSITIF INDONESIA)
}

\author{
Sigit Wibowo \\ Email: ab5161t@yahoo.com \\ Universitas Proklamasi 45 Yogyakarta
}

\begin{abstract}
Abstrak
Pasal 3 Deklarasi Universal Hak Asasi Manusia 1948 menyatakan bahwa "setiap orang memiliki hak untuk hidup, kebebasan, dan keamanan pribadi". Demikian juga dalam pasal 28 huruf A UUD 1945 bahwa "Setiap orang memiliki hak untuk hidup dan memiliki hak untuk mempertahankan kehidupan dan hidupnya". Ini berarti bahwa hak untuk hidup dijamin oleh hukum. Legalisasi Aborsi di Indonesia adalah percakapan yang cukup populer di kalangan aparat penegak hukum dan petugas kesehatan (kedokteran). Selain itu, ini menyangkut aspek interkoneksi-integrasi antara aspek hukum positif dan aspek hukum Islam. Oleh karena itu menimbulkan masalah mengenai bagaimana posisi hukum tindakan aborsi dalam perspektif interkoneksi hukum Islam dan hukum Indonesia yang positif? Posisi hukum Aborsi adalah tindakan yang melanggar hukum dan tidak dibenarkan dalam keadaan apa pun kecuali untuk kepentingan ibu. Ini telah diatur dalam hukum negara, juga dalam hukum Islam termasuk fatwa MUI nomor 4 tahun 2005 yang pada dasarnya melarang karena lebih banyak ruginya daripada manfaatnya. Aborsi memiliki dampak yang sangat berbahaya pada seseorang yang melakukannya, baik dari segi kesehatan maupun sosial, termasuk degradasi moral bagi para pelaku. Pelaku juga dijerat dengan hukuman fisik dalam bentuk penjara setelah menerima keputusan oleh hakim yang telah memperoleh kekuatan hukum. Untuk menghilangkan tingginya tingkat aborsi, termasuk kematian yang disebabkan oleh aborsi yang tidak aman, diperlukan tiga pendekatan, yaitu hukum, medis dan agama, serta moral.
\end{abstract}

Kata Kunci: Hak Asasi Manusia, Aborsi, Hukum

Islam.

Abstract
Article 3 Universal Declaration of Human Rights 1948 states that "everyone has the right to life,
liberty, and security of person". Likewise in article 28 point A of the 1945 Constitution that "Every
person has the right to live and has the right to defend his life and life". This means that the right to
life is guaranteed by law. Legalization of Abortion in Indonesia is a conversation that is quite
popular among law enforcement officials and health workers (medicine). Moreover, it concerns the
interconnective-integration aspects between positive legal aspects and aspects of Islamic law.
Therefore it raises problems regarding how the legal position of abortion acts in the interconnective
perspective of Islamic law and positive Indonesian law? The legal position of Abortion is an act that
violates the law and is not justified under any circumstances except for the benefit of the mother. This
has been regulated in State law, as well as in Islamic law including the Indonesian Religious Leader
(MUI) Fatwa Number 4 of 2005 which essentially prohibits because more harm than benefits.
Abortion has a very dangerous impact on someone who does it, both in terms of health and social,
including moral degradation for the perpetrators. The perpetrator was also ensnared by a physical
sentence in the form of a prison after receiving a decision by a judge who had obtained legal force.
To eliminate the high rate of abortion, including deaths caused by unsafe abortion, three approaches
are needed, namely legal, medical and religious, as well as moral.

Keywords: Human Rights, Abortion, Islamic

Law. 


\section{PENDAHULUAN}

Hidup adalah suatu hal yang berharga dan dilindungi, dalam hukum, hal tersebut tampak pada adanya perlindungan atas hak hidup dan hukuman bagi yang melanggarnya. Article 3 Universal Declaration of Human Right 1948 mencantumkan bahwa "everyone has the right to life, liberty, and security of person”. Begitu pula dalam pasal 28 huruf A Undang-Undang Dasar 1945 bahwa "Setiap orang berhak untuk hidup serta berhak mempertahankan hidup dan kehidupannya", artinya hak untuk hidup dijamin oleh hukum. Kematian di sisi lain sebagai hal yang niscaya juga tidak luput menjadi pembicaraan yang menarik. Plato misalnya, dalam filsafat dualismenya mengatakan bahwa tubuh dalam dunia materi selalu merindu untuk kembali ke dunia idea yang ada setelah yang ragawi berakhir. Dalam kajian lain, Psikoanalisa Freud mengatakan bahwa disamping adanya hasrat hidup yang disebut sebagai eros, manusia juga dibayangi oleh hasrat akan kematian, thanatos yang keduanya berjalan secara berdampingan. Martin
Heidegger, seorang filsuf jerman mengatakan, dalam keterlemparanya dalam dunia, manusia yang disebut sebagai dasein selalu mengarah pada kematian, sebuah finalitas, namun yang penting bagi Heidegger adalah bagaimana kematian tersebut dimaknai oleh seseorang dalam kaitannya dengan ketersingkapan dirinya dengan sang ada. ${ }^{1}$

Mengulas persoalan aborsi dalam perspektif perbandingan hukum khususnya antara Islam dengan sistem hukum lainnya, merupakan hal yang aktual. Aborsi sudah bukan merupakan rahasia umum, dilakukan secara sporadis, tetapi under cover atau dapat dikatakan peristiwanya terjadi dimana-mana, tetapi hukum bersikap tidak tegas dan ambigu. Dalam memandang bagaimana hukumnya aborsi, ternyata telah terjadi pergeseran yang signifikan di berbagai negara, khususnya negara-negara sekuler.

Aborsi merupakan peristilahan yang memberikan persepsi tentang penghilangan nyawa orang lain atau kematian yang dikehendaki dari berbagai

${ }^{1}$ https://rianadhivira.wordpress.com/2012/11/12/e uthanasia-dilema-antara-moral hak hidup-danhukum 
latar belakang alasan baik secara medis maupun secara yuridis. Legalisasi Aborsi di Indonesia merupakan perbincangan yang cukup popular dikalangan aparat penegak hukum dan tenaga kesehatan (kedokteran). Apalagi menyangkut aspek integrasi-interkonektif antara aspek hukum positif dan aspek hukum Islam.

Pendekatan integrasi-interkoneksi memiliki dua sisi terpisah, yaitu sisi integrasi dan sisi interkoneksi. Dalam integrasi restrukturasi ilmu berdasarkan prinsip-prinsip tertentu. Restrukturasi itu dilakukan dengan mengadakan perubahan menyangkut paradigma, teori, metode, dan prosedur-prosedur teknis dalam ilmu pengetahuan, sedangkan dalam interkoneksi tidak terjadi restrukturisasi semacam itu, melainkan yang terjadi adalah perluasan perspektif dengan menyerap informasi pelengkap dari ilmu lain. Atas dasar itu pendekatan interkoneksi dapat dirumuskan sebagai proses pengkajian dalam suatu bidang ilmu dengan memanfaatkan data dan analisis dalam ilmu lain terkait di samping menggunakan data dan analisis ilmu pengetahuan bersangkutan sendiri dalam rangka komplementasi, konfirmasi, kontribusi atau komparasi. ${ }^{2}$

Mengenai aborsi, bukanlah masalah yang baru tapi sudah ada sejak jaman dahulu yang membedakan adalah kadarnya yang semakin lama semakin sering, bahkan sampai saat ini masih banyak pertentangan tentang aborsi. Salah satunya masih banyak negara yang melegalkan aborsi dengan alasan untuk menurunkan angka kematian ibu akibat aborsi illegal. Di lain pihak banyak juga yang berpendapat bahwa tindakan aborsi sama dengan tindakan pembunuhan terhadap manusia dan perampasan hak asasi yaitu hak untuk hidup.

Persoalan aborsi pada umumnya dianggap oleh sebagian besar masyarakat sebagai tindak pidana. Namun, dalam hukum positif di Indonesia, tindakan aborsi pada sejumlah kasus tertentu dapat dibenarkan apabila merupakan abortus provokatus medicialis, sedangkan aborsi yang digeneralisasi menjadi suatu tindak pidana lebih dikenal sebagai abortus provokatus criminalis. Terlepas dari

\footnotetext{
${ }^{2}$ Syamsul Anwar, Interkoneksi Studi Hadits dan Astronomi, Suara Muhammadiyah, Yogyakarta, 2011, hlm, 2-3
} 
persoalan apakah pelaku aborsi melakukannya atas dasar pertimbangan kesehatan (abortus provokatus medicialis) atau memang melakukannya atas dasar alasan lain yang kadang kala tidak dapat diterima oleh akal sehat, seperti kehamilan yang tidak dikehendaki (hamil diluar nikah) atau takut melahirkan ataupun karena takut tidak mampu membesarkan anak karena minimnya kondisi perekonomian keluarga, tetap saja angka kematian akibat aborsi begitu mencengangkan dan sangat memprihatinkan. Data WHO (World Health Organization) menyebutkan bahwa $15-50 \%$ kematian ibu disebabkan oleh pengguguran kandungan yang tidak aman. Dari 20 juta pengguguran kandungan tidak aman yang dilakukan tiap tahun, ditemukan 70.000 perempuan meninggal dunia. Dengan kata lain, 1 dari 8 ibu meninggal dunia akibat aborsi yang tidak aman. Di Indonesia sendiri, angka pembunuhan janin per tahun sudah mencapai 3 juta. Angka yang tidak sedikit mengingat besarnya tingkat kehamilan di Indonesia. Selain itu, ada yg mengkategorikan aborsi itu pembunuhan.
Ada yang melarang atas nama agama. Ada yang menyatakan bahwa jabang bayi juga punya hak hidup sehingga harus dipertahankan, dan lain-lain. Aborsi merupakan masalah kesehatan masyarakat karena memberikan dampak pada kesakitan dan kematian ibu. Sebagaimana diketahui penyebab utama kematian ibu hamil dan melahirkan adalah perdarahan, infeksi dan eklampsia. Namun sebenarnya aborsi juga merupakan penyebab kematian ibu, hanya saja muncul dalam bentuk komplikasi perdarahan dan sepsis. Akan tetapi, kematian ibu yang disebabkan komplikasi aborsi sering tidak muncul dalam laporan kematian, tetapi dilaporkan sebagai perdarahan atau sepsis. ${ }^{3}$

Menyoal aborsi dikaitkan dengan profesi medis atau dunia kedokteran serta dunia hukum di Indonesia belum ada benang merah dalam sistem penegakan hukum serta penanganan aborsi yang aman (safe abortion). Dunia hukum menutup mata atas persoalan ini sekaligus diperparah oleh dunia kedokteran yang

${ }^{3} \mathrm{http}: / /$ suriyadiadhi.blogspot.co.id/2012/12/aborsidalam-perspektif-islam-dan hukum.html 
permisif dan terselubung melakukan praktik yang bertentangan dengan sumpah jabatan. Suatu hal yang menarik dari perdebatan pengesahan undangundang eutanasi di Australia, kelompok yang tidak setuju menegaskan bahwa tugas mulia seorang dokter adalah untuk menyembuhkan/ mengobati si pasien bukan untuk mengakhiri hidup seseorang. Demikian halnya dengan aborsi, secara substansi telah terjadi pembunuhan terhadap janin, bahkan tidak jarang berikut ibunya. ${ }^{4}$

Di dalam KUHP bahwa pasalpasalnya menyiratkan tindak pidana aborsi antara lain adalah Pasal 299, 346, 347, 348, dan 349, yang substansi bahasannya tentang aborsi yang dilakukan oleh seorang wanita, dokter, ahli, atau pihak lain yang tanpa ataupun dengan disengaja menggugurkan kandungan seorang wanita baik melalui persetujuan ataupun tidak dengan persetujuan wanita yang mengandung tersebut.

${ }^{4}$ Ade Maman Suherman, Pengatar Perbandingan Sistem Hukum: Civil Law, Common Law, Hukum Islam, PT Raja Grafindo Persada, Jakarta, 2004, hlm, 224-225.
Demikian halnya dengan Kode Etik Kedokteran yang ditetapkan Menteri Kesehatan Nomor: 434/Men.Kes/SK/X/1983, pada Pasal 10 dinyatakan, bahwa "Setiap dokter harus senantiasa mengingat akan kewajibannya melindungi makhluk insani”. Pada bagian penjelasan Kode Etik Kedokteran ditegaskan bahwa naluri yang kuat pada setiap makhluk yang bernyawa, termasuk manusia ialah mempertahankan hidupnya. Usaha untuk itu merupakan tugas seorang dokter. 5

Aborsi bukanlah semata masalah medis atau kesehatan masyarakat, melainkan juga problem sosial yang terkait dengan paham kebebasan (freedom/liberalism) yang dianut suatu masyarakat. Aborsi juga muncul sebagai sebuah fenomena baik dari kalangan agamawan maupun penegak hukum. Agamawan memandang sebagai tindakan pelanggaran moral karena merenggut hak hidup manusia. Sementara menurut hukum di Indonesia aborsi dipandang sebagai tindakan pidana, karena aborsi

\footnotetext{
${ }^{5}$ http://www.gresnews.com/berita/tips/734182legalisasi-euthanasia-di-indonesia/0/
} 
memang fenomena nyata meskipun kasus yang terjadi lebih banyak ditutupi daripada dilaporkan. Tindakan aborsi juga merupakan tindakan dilematis, karena tidak sedikit dari praktik yang ada justru banyak para ibu yang terenggut nyawanya karena menjalani aborsi.

\section{PERMASALAHAN}

Berdasarkan uraian latar belakang di atas maka dapat dirumuskan suatu masalah yaitu, bagaimanakah kedudukan hukum terhadap tindakan aborsi dalam perspektif interkonektif hukum Islam dan hukum positif Indonesia?

\section{METODE PENELITIAN}

Metode pendekatan yang digunakan dalam penulisan ini adalah dengan yuridis normatif. Pendekatan tersebut dimaksudkan jenis penelitian dogmatis dan bentuk penelitian perskriptif dalam hubungan pada hukum-hukum. Selanjutnya spesifikasi penelitian ini yaitu deskriptif analitis, yakni dengan memberikan gambaran terhadap masalah yang diangkat dan memberikan analisis dari masalah sehingga mampu memberikan jawaban atas permasalahan tersebut.
Metode pengumpulan data dalam penelitian ini adalah menggunakan metode kepustakaan (library research) dengan maksud menguji bahan-bahan dokumen dan bahan pustaka yang digunakan dalam penelitian ini. Data dianalisis secara kualitatif normatif, yaitu melakukan penelitian dengan jalan menafsirkan dan membangun pernyataan yang terdapat dalam dokumen peraturan perundang-undangan. Metode analisis kualitatif, dibangun berdasarkan data dan substansinya yang berasalah atau bersumber dari berbagai literatur seperti buku, jurnal, dan karya ilmiah, peraturan perundang-undangan.

\section{PEMBAHASAN}

\section{A. Pengertian dan Status Hukum} Aborsi

Aborsi merupakan hasil dari propaganda pembatasan jumlah penduduk dan pertumbuhan populasi manusia. Propaganda ini telah lama muncul yaitu diakhir abad ke-18 Masehi. Orang yang pertama kali mempropagandakan ide ini yaitu ide untuk membatasi jumlah penduduk dan pertumbuhan populasi 
manusia adalah "Malthus". Ide ini muncul ketika ia beranggapan bahwa banyaknya jumlah penduduk akan mengakibatkan dampak yang berbahaya bagi sumber daya alam, dimana jumlah penduduk akan terus bertambah secara teknis dan berkesinambungan. Padahal, pada mulanya timbul banyak pertentangan mengenai aborsi baik dari masyarakat maupun pemerintah. Teori Malthus ini diikuti oleh masa berikutnya akan tetapi dengan menggunakan alat-alat pembatasan keturunan. Gerakan ini terus berkembang di Amerika dan disambut hangat dari kalangan penduduk dan negara, sehingga hal ini menjadi tradisi umum sampai terjadi perang dunia pertama tahun 1914-1918. ${ }^{6}$

Istilah aborsi atau abortus secara terminologi berarti keguguran kandungan, penggururan kandungan, atau membuang janin. Dalam terminology kedokteran, berarti terhentinnya kehamilan sebelum 28 minggu. Sedang menurut islitah hukum, berarti pengeluaran hasil konsepsi atau pembuahan dari rahim sebelum

\footnotetext{
${ }^{6}$ http://suriyadiadhi.blogspot.co.id/2012/12/aborsidalam-perspektif-islam-dan-hukum.html
}

waktunya (sebelum dapat lahir secara alamiah). ${ }^{7}$

Dalam kamus Blacks's Law Dictionary, kata abortion diterjemahkan menjadi aborsi dalam bahasa Indonesia, yaitu:

"The spontaneous or articialy induced expulsion of an embrio or featus. As used in illegal content refers to induced abortion" (Keguguran dengan keluarnya embrio atau fetus tidak sematamata karena terjadi secara alamiah, akan tetapi disengaja atau terjadi karena adanya campur tangan (provokasi) manusia. Selanjutnya Fact Abortion, Info Kit on Women's Health oleh Institute for Social Studies and Action, Maret 1991, dalam istilah kesehatan aborsi didefinisikan sebagai penghentian kehamilan setelah tertanamnya telur (ovum) yang telah dibuahi rahim (uterus), sebelum janin (fetus) mencapai 20 minggu". 8

Menurut Suderajat dalam Bunyamin dan Hermanto, ${ }^{9}$ bahwa abortus dalam bahasa Indonesia berasal dari bahasa

\footnotetext{
${ }^{7}$ Suhardi Sukri, et.al, Ensiklopedi, Islam dan Perempuan dari Aborsi Hingga Misogini, Nuansa, Bandung, 2009, hlm, 15

${ }^{8}$ Cecep Triwibowo, Etika dan Hukum Kesehatan, Nuha Medica, Yogyakarta, 2014, hlm,166-167.

${ }^{9}$ Agus Hermanto \& Mahmudin Bunyamin, Fiqh Kesehatan Permasalahan Aktual dan Kontemporer, Pustaka Setia, Bandung, 2016, hlm, 149.
} 
Inggris abortion, yang artinya gugur kandungan atau keguguran. Dalam bahasa Arab, abortus disebut dengan kata isqat al-hamli (menggugurkan kandungan), ijhadh al-hamli (melenyapkan kandungan), al-qau al-hamli (membuang kandungan), dan inzal al-hamli (menurunkan kandungan). Ada beberapa pendapat para ahli tentang abortus, antara lain: Sadikin Ginaputra berpendapat, abortus adalah pengakhiran kehamilan atau konsepsi sebelum janin dapat hidup di luar kandungan; Maryono Reksodipuro, abortus adalah pengeluaran hasil konsepsi (pembuahan ovum oleh sperma) dari rahim sebelum waktunya; M.A. Hanafiyah, abortus adalah keluarnya isi rahim ibu yang telah mengandung hidup insane sebelum waktunya. Dengan demikian, abortus adalah proses untuk mengakhiri masa kehamilan dengan mengeluarkan janin dari kandungan.

Pengertian abortus (secara medis), adalah berakhirnya kehamilan sebelum 20 minggu atau berat janin di bawah 500 gram. Definisi ini berbeda dengan hokum di Negara Inggris, abortus adalah kehilangan janin sebelum 24 minggu ahCG (human chorionic gunadotropin atau penanda kehamilan-red) atau dikenal dengan istilah kehamilan biokimiawi, selanjutnya ultasonografi (USG) berperan dalam mendiagnosis kehamilan. USG dapat memperlihatkan kantung kehamilan yang kosong (blighted ovum), kehamilan dapat terhenti tetapi janin tidak keluar dan mengalami maserasi (kemunduran-red) membentuk masa yang dinamakan fetus kompresus dan fetus papiraseus (missed abortion). Umumnya abortus tejadi spontan dan $80 \%$ abortus terjadi sebelum kehamilan 12 minggu, sebagian dari etiologinya adalah kelainan bawaan. Seperempat wanita hamil pernah mengalami abortus. Dilaporkan sekitar 1 $\%$ pada kejadian abortus terjadi abortus berulang. Abortus berulang pada umumnya ditetapkan apabila kehilangan kehamilan tiga kali berturutan. ${ }^{10}$

Status hukum aborsi dalam hukum nasional setiap negara bervariasi, tetapi

\footnotetext{
${ }^{10}$ Wijayanegara, Hidayat, Aspek Klinis Abortus: Abortus Berulang, PT. Refika Aditama, Bandung, 2009, hlm, 1-3
} 
dapat dikategorikan ke dalam 4 (empat) tingkatan:

"There are roughly four types of laws pertaining to abortion, summarized as follows:

a. Very strict. abortion is not allowed on any grounds, except if the pregnancy poses a threat to the woman's life (e.g. Sri Lanka). Terjemahan bebas: Sangat ketat. aborsi tidak diperbolehkan atas dasar apa pun, kecuali jika kehamilan itu menjadi ancaman bagi kehidupan wanita (misalnya Sri Lanka);

b. Moderate to strict. Only some narrowly defined circumstances justify performing an abortion: for example, threat to the woman's physical or mental health, foetal defect an legal indicators such as rape or incest. Terjemahan bebas: Sedang hingga ketat. Hanya beberapa keadaan yang didefinisikan secara sempit yang membenarkan melakukan aborsi: misalnya, ancaman terhadap kesehatan fisik dan mental wanita, cacat janin, indikator hukum seperti pemerkosaan atau incest;

c. Moderate. Abortion is not only permitted for medical reasons, but for socio-medical or social reasons; for example, low incame, poor housing, young or old age already having a certain number of children; Terjemahan bebas: Moderat. Aborsi tidak hanya diizinkan untuk alasan medis, tetapi untuk alasan sosialmedis atau sosial; misalnya, rendah incame, perumahan miskin, usia muda atau tua sudah memiliki sejumlah anak; d. On request. Woman have the legal rights to dicede the termination of pregnancy. In most cases the rights only applies to the first three month of pregnancy." "11 (Terjemahan bebas: Dalam permintaan. Perempuan memiliki hak hukum untuk membatalkan penghentian kehamilan. Dalam banyak kasus, hak hanya berlaku untuk tiga bulan pertama kehamilan).

\section{Jenis dan Klasifikasi Aborsi}

Menurut dunia kedokteran Aborsi dibagi menjadi dua juga :

a). Aborsi spontan ( Abortus Spontanea ), yaitu merupakan mekanisme alamiah yang menyebabkan terhentinya proses kehamilan sebelum berumur 28 minggu, atau aborsi secara tidak sengaja dan berlangsung alami tanpa ada kehendak dari pihak-pihak tertentu. Masyarakat mengenalnya dengan istilah keguguran. Abortus spontanea merupakan abortus yang

\footnotetext{
${ }^{11}$ Sriani Basnayake, "Selected Paper on Regional Seminar”, Bangalore, India, July, 2000, dalam Ade Maman Suherman, Op Cit, hlm, 226. Sriani Basnayake adalah Direktur Medis dari Asosiasi Keluarga Berencana, Sri Lanka. Lihat pada situs: www.ippf.org/regions/sar/rl/issue6/elminating.ht mmilenium.
} 
berlangsung tanpa

tindakan/pengeluaran janin secara spontan sebelum janin dianggap mampu bertahan hidup. Klasifikasi

abortus spontan, yaitu:

1) abortus imminens; 2) abortus insipiens; 3) abortus inkompletus; 4) abortus kompletus; 5) missed abortion (kehamilan yang tidak normal, janin mati pada usia kurang dari 20 hari dan tidak dapat dihindari, keadaan janin sudah mati tetapi tetap berada dalam rahim dan tidak dikeluarkan selama dua bulan atau lebih); 6) abortus habitulis (keguguran berulang adalah keadaan dimana penderita mengalami keguguran berturutturut 3 kali atau lebih; dan 7) abortus infeksious dan abortus septic, adalah abortus disertai genital;

b) Aborsi buatan (Aborsi Provocatus ), yaitu merupakan suatu upaya yang disengaja untuk mnghentikan proses kehamilan sebelum berumur 28 minggu, dimana janin (hasil konsepsi) yang dikeluarkan tidak bisa bertahan hidup di dunia luar. Aborsi buatan dibedakan dua jenis yaitu:

\section{1) Abortus Provokatus Medicinalis, adalah aborsi}

yang dilakukan oleh dokter atas dasar indikasi medis, yaitu apabila tindakan aborsi tidak diambil akan membahayakan jiwa ibu. Abortus provokatus medicinalis, atau artificialis atau therapeuticus, adalah aborsi yang dilakukan dengan disertai indikasi medis. Indikasi medis adalah demi menyelamatkan nyawa ibu. Adapun syarat-syarat yang ditentukan sebagai indikasi medis adalah:

2) Dilakukan oleh tenaga kesehatan yang memiliki keahlian dan kewenangan untuk melakukannya (Dokter ahli kebidanan dan kandungan) sesuai dengan tanggung jawab profesi;

3) Harus meminta pertimbangan tim ahli (ahli medis, agama, hukum, psikologi);

4) Harus ada persetujuan tertulis dari penderita atau suaminya atau keluarga terdekat;

5) Sarana kesehatan yang memiliki tenaga/ peralatan yang memadai dan ditunjuk oleh Pemerintah;

6) Prosedur tidak dirahasiakan dan dokumen medik harus lengkap.

Dalam praktek jenis abortus ini juga dapat dilakukan jika anak yang akan lahir diperkirakan 
mengalami cacat berat dan harapan hidupnya tipis, misalnya menderita kelainan ectopia kordis (janin akan dilahirkan tanpa dinding dada, sehingga terlihat jantungnya), rakiskisis (jannin akan dilahirkan dengan tulang punggung terbuka tanpa ditutupi kulit, maupun anensefalus (janin akan dilahirkan tanpa otak besar).

c) Abortus

Provocatus

Criminalis adalah aborsi yang terjadi oleh karena tindakantindakan yang tidak legal atau tidak berdasarkan indikasi medis, seperti contoh aborsi yang dilakukan dalam rangka melenyapkan janin sebagai akibat hubungan seksual di luar perkawinan. Secara umum pengertian abortus jenis ini adalah suatu kelahiran dini sebelum bayi itu pada waktunya dapat hidup sendiri di luar kandungan. Umumnya janin yang keluar sudah tidak bernyawa lagi. Dalam aspek yuridis, abortus jenis ini adalah setiap penghentian kehamilan sebelum konsepsi dilahirkan, tanpa memperhitungkan umur bayi dalam kandungan dan janin dilahirkan dalam keadaan mati atau hidup. ${ }^{12}$
2. Pengaturan Aborsi dalam Perspektif Hukum Positif Indonesia

a). Menurut Kitab UndangUndang Hukum Pidana (Lex Genaralis)

Menurut Kitab Undang-undang Hukum Pidana (KUHP) diatur dalam Bab XIV tentang Kejahatan Kesusilaan khususnya Pasal 229, dan Bab XIX Pasal 346 sampai dengan Pasal 349, dan digolongkan kedalam kejahatan terhadap nyawa. KUHP melarang aborsi dan sanksi hukumnya cukup berat. Hukumannya tidak hanya ditujukan kepada wanita yang bersangkutan tetapi semua pihak yang terlibat dalam kejahatan itu.

Tindakan aborsi menurut Kitab Undang-undang Hukum Pidana di Indonesia dikategorikan sebagai tindakan kriminal atau dikategorikan sebagai kejahatan terhadap nyawa. Beberapa pasal dalam Kitab UndangUndang Hukum Pidana (KUHP) yang

\footnotetext{
${ }^{12}$ Cecep Triwibowo, Op.Cit., hlm, 170-172
} 


\author{
mengatur tentang Aborsi (Abortus \\ Provocatus $)^{13}$ :
}

a. Bab XIV Pasal 229 ayat (1) "Barang siapa dengan sengaja mengobati seorang wanita atau menyuruhnya supaya diobati, dengan diberitahukan atau ditimbulkan harapan, bahwa karenapengobatan itu hamilnya dapat digugurkan, diancam dengan pidana penjara paling lama empat tahun atau denda paling banyak tiga ribu rupiah. (2) Jika yang bersalah, berbuat demikian untuk mencari keuntungan, atau menjadikan perbuatan tersebut sebagai pencarian atau kebiasaan, atau jika dia seorang tabib, bidan atau juru obat, pidananya dapat ditambah sepertiga. (3) Jika yang bersalah, melakukan kejahatan tersebut, dalam menjalani pencarian maka dapat dicabut haknya untuk melakukan pencarian itu".

b. Bab XIX Pasal 346 "Seorang wanita yang sengaja menggugurkan atau mematikan kandungannya atau menyuruh orang lain untuk itu, diancam dengan pidana penjara paling lama empat tahun".

13 Theo Lamintang dan Lamintang, Kejahatan Melanggar Norma Kesusilaan dan Norma Kepatutan, PT Sinar Grafika, Jakarta, 2009, hlm, 220
Pasal 347 (1) "Barangsiapa dengan sengaja menggugurkan atau mematikan kandungan seorang wanita tanpa persetujuannya, diancam dengan pidana penjara paling lama dua belas tahun. (2)Jika perbuatan itu mengakibatkan matinya wanita tersebut, dikenakan pidana penjara paling lama lima belas tahun".

Pasal 348 (1) "Barangsiapa dengan sengaja menggugurkan atau mematikan kandungan seorang wanita dengan persetujuannya, diancam dengan pidana penjara paling lama lima tahun enam bulan. (2) Jika perbuatan itu mengakibatkan matinya wanita tersebut, dikenakan pidana penjara paling lama tujuh tahun".

Pasal 349 "Jika seorang tabib, bidan atau juru obat membantu melakukan kejahatan yang tersebut pasal 346, ataupun melakukan atau membantu melakukan salah satu kejahatan yang diterangkan dalam pasal 347 dan 348, maka pidana yang ditentukan dalam pasal itu dapat ditambah dengan sepertiga dan dapat dicabut hak untuk menjalankan pencarian dalam mana kejahatan dilakukan”.

Berdasar pada rumusan pasalpasal KUHP tersebut dapat ditarik kesimpulan bahwa:

1) Seorang perempuan hamil yang dengan sengaja melakukan aborsi atau ia 
menyuruh orang lain, diancam hukuman empat tahun penjara;

2) Seseorang yang dengan sengaja melakukan aborsi terhadap ibu hamil dengan tanpa persetujuan ibu hamil tersebut, diancam hukuman penjara 12 tahun, \& jika ibu hamil tersebut mati, diancam penjara 15 tahun penjara;

3) Jika dengan persetujuan ibu hamil, maka diancam hukuman 5,5 tahun penjara \& bila ibu hamil tersebut mati diancam hukuman 7 tahun penjara;

4) Jika yang melakukan \& atau membantu melakukan aborsi tersebut seorang dokter, bidan atau juru obat ancaman hukumannya ditambah sepertiganya \& hak untuk berpraktik dapat dicabut;

5) Setiap janin yang dikandung sampai akhirnya nanti dilahirkan berhak untuk hidup serta mempertahankan hidupnya.

b). Undang-Undang Nomor 36 Tahun 2009 tentang Kesehatan (Lex Spesialis)

Pengaturan mengenai praktik aborsi diatur di dalam Undang-Undang Republik Indonesia Nomor 36 Tahun 2009 tentang Kesehatan. Pada prinsipnya, setiap orang dilarang melakukan aborsi, sebagaimana dimaksud di dalam Pasal 75 ayat (1), ayat (2), ayat (3) UU Kesehatan berikut ini:

"Ayat (1) Setiap orang dilarang melakukan aborsi.

Ayat (2) "Larangan sebagaimana dimaksud pada ayat (1) dapat dikecualikan berdasarkan: (a) Indikasi kedaruratan medis yang dideteksi sejak usia dini kehamilan, baik yang mengancam nyawa ibu dan/atau janin, yang menderita penyakit genetic berat dan/atau cacat bawaan, maupun yang tidak dapat diperbaiki sehingga menyulitkan bayi tersebut hidup di luar kandungan; atau (b) Kehamilan akibat perkosaan yang dapat menyebabkan trauma psikologis bagi korban perkosaan".

Ayat (3) "Tindakan sebagaimana dimaksud pada ayat (2) hanya dapat dilakukan setelah melalui konseling dan/atau penasehatan pra tindakan dan diakhiri dengan konseling pasca tindakan yang dilakukan oleh konselor yang kompeten dan berwenang".

Menurut Pasal 76 UU Kesehatan menyatakan syarat-syarat boleh dilakukannya aborsi. Aborsi sebagaimana dimaksud dalam Pasal 75 hanya dapat dilakukan:

a. Sebelum kehamilan berumur 6 (enam) minggu dihitung dari hari pertama haid terakhir, kecuali dalam hal kedaruratan medis;

b. Oleh tenaga kesehatan yang memiliki keterampilan dan kewenangan yang 
memiliki sertifikat yang ditetapkan oleh menteri;

c. Dengan persetujuan ibu hamil yang bersangkutan;

d. Dengan izin suami, kecuali korban perkosaan; dan

e. Penyedia layanan kesehatan yang memenuhi syarat yang ditetapkan oleh Menteri.

Ancaman pidana untuk pelanggar pasal 75 ayat (2) UU Kesehatan di atas terdapat di dalam Pasal 194 UU Kesehatan berikut ini:

"Setiap orang yang dengan sengaja melakukan aborsi tidak sesuai dengan ketentuan sebagaimana dimaksud dalam Pasal 75 ayat (2) dipidana dengan pidana penjara paling lama 10 (sepuluh) tahun dan denda paling banyak Rp1.000.000.000,00 (satu miliar rupiah)”.

\section{c). Fatwa Majelis Ulama Indonesia Nomor 4 TAHUN 2005 tentang A B O R S I}

Fatwa MUI Kedua tentang Ketentuan Hukum:

a. Aborsi haram hukumnya sejak terjadinya implantasi blastosis pada dinding rahim ibu (nidasi).

b. Aborsi dibolehkan karena adanya uzur, baik yang bersifat darurat ataupun hajat.

1) Keadaan darurat yang berkaitan dengan kehamilah yang membolehkan aborsi adalah: a) Perempuan hamil menderita sakit fisik berat seperti kanker stadium lanjut, TBC dengan caverna dan penyakit-penyakit fisik berat lainnya yang harus ditetapkan oleh Tim Dokter; b) Dalam keadaan di mana kehamilan mengancam nyawa si ibu.

2) Keadaan hajat yang berkaitan dengan kehamilan yang dapat membolehkan aborsi adalah:

a) Janin yang dikandung dideteksi menderita cacat genetic yang kalau lahir kelak sulit disembuhkan; b) Kehamilan akibat perkosaan yang ditetapkan oleh Tim yang berwenang yang didalamnya terdapat antara lain keluarga korban, dokter, dan ulama; dan c) Kebolehan aborsi sebagaimana dimaksud huruf $b$ harus dilakukan sebelum janin berusia 40 hari.

c. Aborsi haram hukumnya dilakukan pada kehamilan yang terjadi akibat zina.

\section{Aborsi dalam Perspektif}

\section{Hukum Islam}

Istilah syari'at, aborsi adalah kematian janin atau keguguran sebelum sempurna; walaupun janin belum mencapai usia enam bulan. Dari sini dapat disimpulkan bahwa aborsi secara syari'at tidak melihat kepada usia kandungan, namun melihat kepada 
kesempurnaan bentuk janin tersebut. yang sedang mengalami pertumbuhan dan Ijhadh (aborsi) menurut bahasa berarti menggugurkan kandungan yang kurang masanya atau kurang kejadiannya, tidak ada perbedaan antara kehamilan anak permpuan atau laki-laki, baik aborsi ini dilakukan dengan sengaja atau tidak. Lafazh ijhadh memiliki beberapa sinonim seperti isqath (menjatuhkan), ilqa' (membuang), tharah (melempar), dan imlash (menyingkirkan).

Aborsi diperbolehkan sebelum peniupan ruh, antara lain Muhammad Ramli (1596 M) dalam kitabnya An Nihayah dengan alasan karena belum ada makhluk yang bernyawa. Ada pula yang memandangnya makruh, dengan alasan karena janin sedang mengalami pertumbuhan. Aborsi diharamkan sebelum peniupan ruh antara lain Ibnu Hajar (1567 M) dalam kitabnya At Tuhfah dan Al-Ghazali dalam kitabnya Ihya' Ulumiddin. Bahkan Mahmud Syaltut, mantan Rektor Universitas Al-Azhar Mesir berpendapat bahwa sejak bertemunya sel sperma dengan ovum (sel telur) maka aborsi adalah haram, sebab persiapan untuk menjadi makhluk baru yang bernyawa yang bernama manusia yang harus dihormati dan dilindungi eksistensinya. ${ }^{14}$

Pendapat yang disepakati fuqoha, yaitu bahwa haram hukumnya melakukan aborsi setelah ditiupkannya ruh (empat bulan), didasarkan pada kenyataan bahwa peniupan ruh terjadi setelah 4 (empat) bulan masa kehamilan. Berdasarkan dalil-dalil ini maka aborsi adalah haram pada kandungan yang bernyawa atau telah berumur 4 bulan, sebab dalam keadaan demikian berarti aborsi itu adalah suatu tindak kejahatan pembunuhan yang diharamkan Islam. Dalil syar'i yang menunjukkan bahwa aborsi haram bila usia janin 40 hari atau 40 malam atau lebih adalah hadis Nabi s.a.w berikut:

"Jika nutfah (gumpalan darah) telah lewat empat puluh dua malam, maka Allah mengutus seorang malaikat padanya, lalu dia membentuk nutfah tersebut; dia membuat pendengarannya,

\footnotetext{
${ }^{14}$ (http://suriyadiadhi.blogspot.co.id/2012/12/abors

i-dalam-perspektif-islam-dan-hukum.html).
} 
penglihatannya, kulitnya, dagingnya, dan tulang belulangnya. Lalu malaikat itu bertanya (kepada Allah),'Ya Tuhanku, apakah dia (akan Engkau tetapkan) menjadi laki-laki atau perempuan?' Maka Allah kemudian memberi keputusan..." (HR. Muslim dari Ibnu Mas'ud r.a).

Hadist di atas menunjukkan bahwa permulaan penciptaan janin dan penampakan anggota-anggota tubuhnya, adalah setelah melewati 40 atau 42 malam. Dengan demikian, penganiayaan terhadapnya adalah suatu penganiayaan terhadap janin yang sudah mempunyai tanda-tanda sebagai manusia yang terpelihara darahnya (ma'shumud dam), sedangkan aborsi pada janin yang usianya belum mencapai 40 hari, maka hukumnya boleh (ja'iz) dan tidak apa-apa. Ini disebabkan bahwa apa yang ada dalam rahim belum menjadi janin karena dia masih berada dalam tahapan sebagai nutfah (gumpalan darah), belum sampai pada fase penciptaan yang menunjukkan ciri-ciri minimal sebagai manusia.

Di samping itu, pengguguran nutfah sebelum menjadi janin, dari segi hukum dapat disamakan dengan 'azl (coitus interruptus) yang dimaksudkan untuk mencegah terjadinya kehamilan. 'Azl dilakukan oleh seorang laki-laki yang tidak menghendaki kehamilan perempuan yang digaulinya, sebab 'azl merupakan tindakan mengeluarkan sperma di luar vagina perempuan. Tindakan ini akan mengakibatkan kematian sel sperma, sebagaimana akan mengakibatkan matinya sel telur, sehingga akan mengakibatkan tiadanya pertemuan sel sperma dengan sel telur yang tentu tidak akan menimbulkan kehamilan.

Namun demikian, dibolehkan melakukan aborsi baik pada tahap penciptaan janin, ataupun setelah peniupan ruh padanya, jika dokter yang terpercaya menetapkan bahwa keberadaan janin dalam perut ibu akan mengakibatkan kematian ibu dan janinnya sekaligus. Dalam kondisi seperti ini, dibolehkan melakukan aborsi dan mengupayakan penyelamatan kehidupan jiwa ibu.

\section{- Hukum Abortus}

Bahwa kehidupan janin (anak dalam kandungan) menurut pandangan syari'at Islam merupakan kehidupan yang harus dihormati, dengan menganggapnya sebagai suatu wujud yang hidup yang 
wajib dijaga. Karena itu syari'at Islam mengharamkan tindakan yang melampaui batas terhadapnya. Meskipun yang melakukan ayah atau ibunya sendiri yang telah mengandungnya dengan susah payah. Bahkan terhadap kehamilan yang haram, yang dilakukan dengan jalan perzinahan, janinnya tetap tidak boleh digugurkan, karena ia merupakan manusia hidup yang tidak berdosa.

Allah berfirman dalam QS. Al-Israa ayat (31), yang artinya:

"Dan janganlah kamu membunuh anak-anakmu Karena takut kemiskinan. kamilah yang akan memberi rezeki kepada mereka dan juga kepadamu. Sesungguhnya membunuh mereka adalah suatu dosa yang besar".

\section{- Klasifikasi dan Syari'at Abortus}

Keguguran atau abortus (al-Ijhâdh) dapat diklasifikasikan dalam tiga jenis:

1) Al-Ijhâdh at-Tilqâ'i atau al-'Afwi (Abortus spontanea) yaitu proses alami yang dilakukan rahim untuk mengeluarkan janin yang tidak mungkin sempurna unsur-unsur kehidupan padanya. Bisa jadi ini terjadi dengan sebab kecacatan besar yang menimpanya karena akibat sakitnya sang ibu yang terkena penyakit beragam seperti diabetes atau lainnya;

2) Al-Ijhâdh al-'Ilâji (Abortus ProvokatusMedisinalis/Artificialis/Th erapeuticus) adalah abortus (keguguran) yang sengaja dilakukan para medis (dokter) demi menyelamatkan nyawa ibu yang dalam keadaan sangat jarang bahwa kehamilannya dapat berlanjut dengan selamat;

3) Al-Ijhâdh al-Ijtimâ-'i dinamakan juga al-Ijhâdh al-Jinâi atau al-Ijrâmi (Abortus Provokatus Kriminalis) adalah aborsi yang sengaja dilakukan tanpa adanya indikasi medik (illegal). Tujuannya hanya untuk tidak melahirkan bayi atau untuk menjaga penampilan atau menutupi aib dan sejenisnya. Biasanya pengguguran dilakukan dengan menggunakan berbagai cara termasuk dengan alatalat atau obat-obat tertentu.

Syaikh Ahmad al-Ghazâli seorang Ulama Indonesia menyatakan: "Adapun ulama Indonesia berpendapat keharaman aborsi kecuali apabila ada dengan sebab terpaksa yang harus dilakukan dan menyebabkan kematian sang ibu. Hal ini karena syari'at Islam dalam keadaan seperti itu memerintahkan untuk melanggar salah satu madharat yang teringan. Apabila tidak ada di sana solusi lain selain menggugurkan janin untuk menjaga hidup sang ibu". 


\section{Interrelasi Hukum dan Moral}

\section{Hukum}

$\begin{array}{ccc}\text { Interrelasi } & \text { Hukum dan Moral } \\ \text { Hukum ialah } & \text { sebagai } & \text { pengaturan }\end{array}$
perbuatan-perbuatan manusia oleh kekuasaan sah bukan hanya keputusan (peraturan-peraturan yang dirumuskan) melainkan juga dalam pelaksanaanya, sesuai dengan ideologi bangsa sebagai pengayom yang melembaga dari rakayat (umat manusia) berdasarkan hukum kodrati, sedangkan moral, adalah pengaturan perbuatan manusia sebagai manusia ditinjau dari segi baik buruknya dari hubungannya dengan tujuan akhir hidup manusia berdasarkan hukum kodrati. ${ }^{15}$ Dengan demikian nampak jelas bahwa baik hukum maupun moral keduaduanya mengatur perbuatan-perbuatan manusia sebagai manusia. Kedua-duanya terdiri atas norma-norma yang mengatur perbuatan-perbuatan manusia.

Menurut aliran Positivis, bahwa dasar satu-satunya dari hukum yang sejati adalah hukum kodrati (hukum alam). ${ }^{16}$

15 A. Gunawan Setiarja, Dialetika Hukum dan Moral dalam Pembangunan Masyarakat Indonesia, Kanisius, Yogyakarta, 1990, hlm, 113

${ }^{16}$ Ibid, hlm, 115
Ajaran Thomas Aquinas tentang hukum memiliki dua jenis, yaitu Hukum Kodrat dan Hukum Positif. Hukum Positif oleh Thomas dibagi lagi dalam dua jenis, hukum positif "buatan manusia" (lex positiva humana) dan hukum positif "illahi” (lex positive divina). Hukum positif buatan manusia, dalam pengembangannya, meliputi hukumhukum yang dimiliki oleh masing-masing bangsa dan konsep hokum publik. Kontribusi ajaran Thomas tentang hukum pada pengembangan teori hokum terutama tampak dalam konsep ius (hak), konsep yang mendasari gagasan modern tentang hak-hak asasi manusia. ${ }^{17}$

Menurut Thomas Aquinas hubungan hukum dan moralitas ${ }^{18}$ dinyatakan, bahwa hukum sebagai aturan dan ukuran perbuatan yang mengarahkan atau melarang manusia berbuat. Jika mengarahkan perbuatan, maka aturan dan ukuran tersebut membimbing manusia mencapai kebaikan individualnya, yaitu pemenuhan kesempurnaan kodrat

17 E. Sumaryono, Etika dan Hukum, Relevansi Teori Hukum Kodrat Thomas Aquinas, Kanisius, Yogyakarta, 2002, hlm, 251

${ }^{18}$ Ibid, hlm, 254 
rasional. "Kebaikan" hanya dapat adalah sebagai kesesuaian atau terwujud jika ada cinta manusia terhadap sesamanya, dan cinta ini hanya akan terwujud jika ada keadilan.

Lebih lanjut dijelaskan oleh Thomas, bahwa hukum dapat dianggap adil jika, di satu sisi, hukum dapat menjamin obyektifitas antara subyek dengan sesuatu yang secara kodrat menjadi haknya (hak kodrat), yaitu "hak yang inheren" di dalam kodrat manusia sebagai persona. Hal inilah yang menjadi dasar definisi "hukum kodrat" sebagai partisipasi atas hukum abadi di dalam mahkluk rasional. Di sisi lain, hukum disebut adil jika hukum tersebut berfungsi efektif dalam menjamin atau melindungi hak-hak subyek yang diaturnya, baik yang diatur di dalam hukum positif (hak positif) maupun yang didasarkan atas perjanjian antar pribadi warga Negara (hak moral). ${ }^{19}$

Menurut Immanuel Kant dalam Metafisika kesusilaan (1797) membuat distingsi antara legalitas dan moralitas. ${ }^{20}$

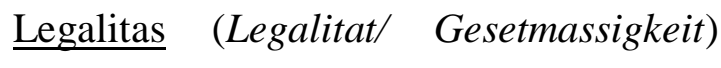

${ }^{19}$ Ibid, hlm, 255

${ }^{20}$ S.P. Liti Tjahjadi, Hukum Moral Ajaran Immanuel Kant tentang Etika dan Imperative Kategoris, Kanisius, Yogyakarta, 1991, hlm, 47

ketidaksesuaian semata-mata suatu tindakan dengan hukum dan norma lahirilah belaka. Kesesuaian atau ketidaksesuaian ini pada dirinya sendiri belum bernilai moral, sebab dorongan batin (Tribfeder) sama sekali tidak diperhatikan. Nilai moral baru diperoleh di dalam moralitas. Moralitas (Moralitat) Sittilichkeit) adalah kesesuaian sikap dan perbuatan manusia dengan norma atau hukum batiniah manusia, yakni apa yang dipandang sebagai kewajiban manusia. Moralitas akan tercapai apabila manusia mentaati hukum lahiriah bukan lantaran hal itu membawa akibat yang menguntungkan manusia atau lantaran takut pada kuasa sang pemberi hukum, melainkan manusia sendiri menyadari bahwa hukum itu merupakan kewajiban mansuia.

Dengan demikian Moralitas dipahami Kant sebagai kesesuaian tindakan manusia dengan norma batiniah, yakni kesadaran hati manusia akan kewajiban manusia. Bertindak moral berarti bertindak demi kewajiban semata-mata, bukan untuk mncapai tujuan tertetnu atau 
tergerak oleh kecenderungankecenderungan emosional. Keharusan agar manusia bertindak demi kewajiban semata-mata diungkapkan dengan istilah "imperative kategoris" yakni perintah yang mutlak berlaku selalu dan dimanamana. Jadi merupakan perintah tidak bersyarat. Sedangkan "imperative hipotetis" sebagai perintah bersyarat yang menyatakan suatu tindakan tertetentu untuk mecapai tujuan lebih lanjut. Jadi tindakan yang merupakan sarana untuk mencapai tujuan. ${ }^{21}$ Seperti penerapan hukuman bagi subyek hukum yang melanggar hukum (tindak pidana, misalnya melakukan aborsi maupun euthanasia) maka bagi siapa saja yang melanggar terkena sanksi pidana).

Mencermati dari beberapa aliran dan pandangan tersebut, maka benang merahnya antara hukum dan moral justru terletak pada hukum alam. Dalam hukum alam itu ditemukan dialektika ${ }^{22}$ antara

\footnotetext{
${ }^{21}$ Ibid, hlm, 64

22 A. Gunawan Setiardja, Op.Cit, hlm, 113. Dialektika atau berpikir dialektis adalah 1) berpikir konkret, berpikir integral, menyeluruh; 2) melihat realitas tidak statis, melainkan meliat realitas ini dalam dinammikanya; 3) melihat suatu kejadian terkait dengan pribadi.
}

hukum dan moral. Moral mencakup dan mengatur hidup manusia dalam segala seginya, mangatur hidup baik batin maupun lahir manusia. Dari segi etis $\underline{\text { hukum, }}$ termasuk keterlibatan dan peran dalam proses pembentukan hukum (anggota legislative, pejabat eksekutif, pejabat kehakiiman/ pengadilan, para ahli huku, filsuf hukum) yang member sumbangan yang berharga, dan selalu ingat pada hukum alam. Hukum yang harus disusun, harus mengingat martabat dan harkat manusia sebagai pribadi. Para pembentuk dan pemikir hukum harus menciptakan tatanan hukum dalam mana manusia dapat mencapai penyempurnannya secara sebaikbaiknya. $^{23}$

\section{Relasi Perilaku dan Moral dalam Aborsi}

Perusahaan riset Internasional Synovate atas nama DKT Indonesia melakukan penelitian terhadap perilaku seksual remaja berusia 14-24 tahun yang dilakukan terhadap 450 remaja dari Medan, Jakarta, Bandung dan Surabaya. Terungkap bahwa $64 \%$ remaja mengakui

${ }^{23}$ Ibid, hlm, 116-117 
secara sadar melakukan hubungan seks pranikah dan telah melanggar nilai-nilai dan norma agama, tetapi kesadaran itu ternyata tidak mempengaruhi perbuatan dan prilaku seksual mereka. Alasan para remaja melakukan hubungan seksual tersebut adalah karena semua itu terjadi begitu saja tanpa direncanakan. Hasil penelitian juga memaparkan para remaja tersebut tidak memiliki pengetahuan khusus serta komprehensif mengenai seks. Informasi tentang seks (65\%) mereka dapatkan melalui teman, Film Porno (35\%), sekolah (19\%), dan orangtua (5\%). Dari persentase ini dapat dilihat bahwa informasi dari teman lebih dominan dibandingkan orangtua dan guru, padahal teman sendiri tidak begitu mengerti dengan permasalahan seks ini, karena dia juga mentransformasi dari teman yang lainnya. Kurang perhatian orangtua, kurangnya penanaman nilainilai agama berdampak pada pergaulan bebas dan berakibat remaja dengan gampang melakukan hubungan suami istri di luar nikah sehingga terjadi kehamilan dan pada kondisi ketidaksiapan berumah tangga dan untuk bertanggung jawab terjadilah aborsi. Seorang wanita lebih cendrung berbuat nekat (pendek akal) jika menghadapi hal seperti ini. Pada zaman modern sekarang ini, remaja sedang dihadapkan pada kondisi sistem- sistem nilai, dan kemudian sistem nilai tersebut terkikis oleh sistem nilai yang lain yang bertentangan dengan nilai moral dan agama. Seperti model pakaian (fashion), model pergaulan dan film-film yang begitu intensif remaja mengadopsi kedalam gaya pergaulan hidup mereka termasuk soal hubungan seks di luar nikah dianggap suatu kewajaran. Beberapa faktor yang menyebabkan terjadinya pergaulan bebas dikalangan remaja yaitu faktor agama dan iman; faktor Lingkungan seperti orangtua, teman, tetangga dan media; pengetahuan yang minim ditambah rasa ingin tahu yang berlebihan; dan perubahan zaman. ${ }^{24}$

Dengan demikian tindakan aborsi merupakan tindakan yang melanggar

\footnotetext{
${ }^{24}$ (http://www.slideshare.net/ferailma/aborsidalam-tinjauan-etika-hukum-positif-dan-hukumislam)
} 
nilai-nilai etika, baik ditinjau dari segi etika budaya/ etika bermasyarakat, etika hukum maupun etika agama. Oleh karena itu perilaku semacam ini harus dihindari bahkan dijauhi dari seluruh lapisan masyarakat, meskipun dalam kondisi tertentu diperbolehkan.

\section{Faktor-faktor Adanya Praktek} Aborsi

1. Faktor-faktor

Pendorong

dilakukan aborsi antara lain:

a. Atas Indikasi Medis, yaitu 1) Menyelematkan ibu karena kelanjutan kehamilan yang dipertahankan akan mengancam dan membahayakan jiwa ibu. Aborsi ini dilakukan oleh dokter atas dasar indikasi medis, yang menunjukkan bahwa jika tidak dilakukan aborsi, akan membahayakan jiwa ibu; 2) Menghindarkan kemungkinan terjadinya cacat jasmani dan rohani apabila janin dilahirkan;

b. Abortus atau atas Indikasi Sosial yang disebabkan hal-hal berikut: 1) Kegagalan menggunakan alat kontrasepsi atau dalam usaha mencegah kehamilan; 2) Ingin menutupi aid, seperti dilakukan oleh orang yang belum bersuami atau dilakukan oleh wanita yang telah bersuami karena terdorong oleh godaan dan kenikmatan sekejap; 3) Kesulitan ekonomi sehingga kelahiran anak tidak diharapkan, bahkan dianggap belum hidup; dan 4) Kehamilan yang terjadi akibat perkosaan, tentu saja kehadiran anak yang dalam keadaan sengat tidak diharapkan walaupun anak tersebut tidak berdosa. ${ }^{25}$

2. Faktor-faktor Penyebab dilakukan aborsi, lainnya:

Menurut AGI (Alan Guttmacher Institute) alasan mengapa wanita melakukan aborsi, diantaranya disebabkan oleh sejumlah alasan dan persoalan seorang abortee, yaitu:

a. Wanita ingin membatasi atau menangguhkan perawatan anak;

b. Alasan social ekonomi untuk mengakhiri kehamilan;

c. Tidak mampu membiayai untuk membesarkan anak;

d. Ingin melanjutkan pendidikan atau karier;

e. Alasan atau akibat hubungan yang bermasalah atau kehamilan karena perkosaan atau incest;

f. Alasan usia terlalu muda atau terlalu tua untuk mempunyai bayi atau;

g. Alasan bahwa kehamilan akan mempengaruhi kesehatan dirinya sendiri maupun bayinya. ${ }^{26}$

\footnotetext{
${ }^{25}$ Agus Hermanto dan Mahmudin Bunyamin, Op.Cit., hlm, 151-152

26 Planned Parenthood Federation of America, Fact Sheet, Desember 2000, dari AGI, "Sharing Responsibility: Woman, Society, and Abortion
} 


\section{B. Dampak Abortus}

Menurut Hasan dalam Bunyamin dan Hermanto, ${ }^{27}$ bahwa dampak atau risiko abortus yaitu: a) Timbul luka dan infeksi dalam dinding alat kelamin dan merusak organ-organ didekatnya, seperti kandung kemih dan usus; b) Robek mulut rahim sebelah kanan; c) Dinding rahim bisa tembus karena alat-alat yang dimasukkan ke dalamnya; dan e) Pendarahan akibat dari penggunan obat-obatan.

\section{KESIMPULAN}

Berdasarkan pembahasan pada uraian tersebut di atas maka, dapat dikemukakan suatu simpulan, bahwa Aborsi merupakan tindakan yang melanggar hukum dan tidak dibenarkan dalam kondisi apapun kecuali untuk kemaslahatan si ibu. Hal ini sudah diatur dalam hukum Negara, maupun dalam hukum Islam termasuk Fatwa MUI No. 4 Tahun 2005 yang intinya mengharamkan karena lebih banya mudharatnya dari pada manfaatnya. Aborsi memiliki dampak yang sangat berbahaya bagi seorang yang melakukanya, baik dari segi kesehatan maupun sosial, termasuk degradasi moral bagi pelakunya. Pelaku juga terjerat hukuman fisik berupa penjara dengan setelah mendapat putusan Hakim yang telah memperoleh kekuatan hukum. Tingginya angka kematian akibat aborsi perlu direspons oleh pemerintah dengan menyediakan fasilitas aborsi yang aman dan legal. Untuk mengeliminasi tingginya aborsi termasuk kematian yang diakibatkan oleh aborsi yang tidak aman perlu dilakukan tiga pendekatan, yaitu pendekatan hukum, medis dan agama, serta moral.

World wide, New York: Alan Guttmacher, 1999, dalam Ade Maman Suherman, Op Cit, 230.

${ }^{27}$ Ibid 


\section{DAFTAR PUSTAKA}

\section{A. Buku}

Anwar, Syamsul, Interkoneksi Studi Hadis dan Astronomi, Suara Muhammadiyah, Yogyakarta, 2011

Basnayake, Sriani, "Selected Paper on Regional Seminar”, Bangalore, India, July, 2000

Guttmacher, Alan, Planned Parenthood Federation of America, Fact Sheet, Desember 2000, dari AGI, "Sharing Responsibility: Woman, Society, and Abortion World wide, New York: 1999

Hermanto, Agus dan Bunyamin, Mahmudin, Fiqh Kesehatan Permaslahan Aktual dan Kontemporer, Pustaka Setia, Bandung, 2016

Lamintang, Theo dan Lamintang, Kejahatan Melanggar Norma Kesusilaan dan Norma Kepatutan, PT Sinar Grafika, Jakarta, 2009

Setiardja, Gunawan A., Dialetika Hukum dan Moral dalam Pembangunan Masyarakat
Indonesia, Kanisus, Cet. Pertama, Yogyakarta, 1990.

Suherman, Ade Maman, Pengatar Perbandingan Sistem Hukum: Civil Law, Common Law, Hukum Islam, PT Raja Grafindo Persada, Jakarta, 2004

Sumaryono, E., Etika dan Hukum Relevansi Teori Hukum Kodrat Thomas Aquinas, Kanisius, Yogyakarta, 2002

Sukri, Suhardi at al, Ensiklopedi, Islam dan Perempuan dari Aborsi Hingga Misogini, Nuansa, Bandung, 2009

Tjahjadi, Lili, SP., Hukum dan Moral Ajaran Immanuel Kant tentang Etika dan Imperatif Kategoris, Kanisius, Yogyakarta, 1991

Triwibowo, Cecep, Etika dan Hukum Kesehatan, Nuha Medica, Yogyakarta, 2014

\section{B. Peraturan Perundang-undangan}

Undang-Undang Dasar 1945

Kitab Undang-Undang Hukum Pidana Undang-Undang Nomor 36 Tahun 2009 tentang Kesehatan 
HUKUM ABORSI DALAM PERSPEKTIF INTERKONEKTIF (TINJAUAN DARI HUKUM ISLAM DAN HUKUM POSITIF INDONESIA): Sigit Wibowo

Fatwa Majelis Ulama Indonesia Nomor 4

Tahun 2005 tentang Aborsi

\section{Sumber Lainnya}

http://sahabatrianti.blogspot.co.id/2014/0

5/makalah-aborsi-euthanasia-bayi-

tabung.html

http://www.solusihukum.com/kasus2.php

http://www.gresnews.com/berita/tips/7341

82-legalisasi-euthanasia-di-

indonesia/0/

http://www.slideshare.net/ferailma/aborsi

-dalam-tinjauan-etika-hukum-

positif-dan hukum islam

http://suriyadiadhi.blogspot.co.id/2012/12

/aborsi-dalam-perspektif-islam-dan

hukum.html 